\title{
The Factors Predicting Students' Satisfaction with University Hostels, Case Study, Universiti Sains Malaysia
}

\author{
Fatemeh Khozaei (Corresponding author) \\ School of Housing Building and Planning, Universiti Sains Malaysia \\ 11800 Minden Pulau Pinang, Malaysia \\ Tel: 60-1-7499-3056 E-mail: fatemeh.rd08@student.usm.my
}

Nadia Ayub

Department of Social Sciences, College of Business Management

Institute of Business Management at Korangi Creek, 75190, Karachi, Pakistan

Tel: 92-0-21-111-002-004Ｅ-mail: nadia.ayub@iobm.edu.pk

\author{
Ahmad Sanusi Hassan \\ School of Housing Building and Planning, \\ Universiti Sains Malaysia, 11800 Minden Pulau Pinang, Malaysia \\ Tel: 60-4-653-2835Ｅ-mail: sanusi@usm.my
}

\author{
Zahra Khozaei \\ School of Humanities, Universiti Sains Malaysia, 11800 Minden Pulau Pinang, Malaysia \\ Tel: 60-1-7499-3196 E-mail: zahra_khozaei.hd06@student.usm.my
}

\begin{abstract}
This study was administrated to undergraduate students living in the various hostels of Universiti Sains Malaysia. The primary purpose of this study was to identify the most important factors that predict undergraduate students' level of satisfaction with the student hostels they are living in. This paper also explored the difference in the satisfaction levels of students living in hostels within the campus and those living in hostels outside the campus. Based on literature review, it was hypothesized that there would be a difference in the satisfaction level between these two groups of hostel residents due to the different characteristics that these hostels have. Additionally, this study investigated the most preferred hostels among students and identified the reasons for the preference. A sample population of 288 students ( 220 females; and 68 males) was involved in this study with $48.3 \%$ living in hostels inside the campus and 51.7\% living in hostels located outside the main campus area. The result of the study suggests that satisfaction with fees, distance from university facilities, room safety, room size, hostel security, and hostel facilities are the most important factors which predict undergraduate students' satisfaction with their hostel. There was also a significant difference in the satisfaction level between inside-campus and outside-campus hostels students. The most important factors that influenced that students satisfaction levels were distance from the university facilities, the exterior condition of the hostel, hostel population, satisfaction with transport, hostel security, room size, and room safety. The study also found that the most preferred hostel among the students was Cahaya Gemilang due to its strategic location, close distance to lecture halls and other main facilities in the campus and, good internet network connection.
\end{abstract}

Keywords: Satisfaction, Hostels, Predicting factors, Undergraduate students

\section{Introduction}

Residing in students' housing, faraway from family for a long period of time, is an enduring experience for young students. This new life style provides an opportunity to learn how to live independently, compromise with other students and roommates, share space and facilities and so forth. The influence of the environment and 
accommodation on the satisfaction level of university students has been a popular area of study and of compelling interest to universities. In relation to this, such studies indicates that good hostel condition and facilities in university campuses have a positive influence on the overall student enrollment (Bekurs, 2007).

Although there are many studies that investigate factors influencing residents' satisfaction with their homes and neighborhood, there seems to be a lack of inquiry into students' satisfaction with their university housing (Amole 2009). In studies that place the critical lens on students' satisfaction levels of their university accommodation, the units of focus have been diverse such as on the influence of the physical attributes, and, psychological and management aspects. Most of these studies indicate that there is a direct co-relation between the satisfaction levels and the hostel environment. Basically, when the environment meets the individuals' expectation a higher degree of satisfaction has been noted. On the other hand, incongruence between housing needs and aspirations leads to dissatisfaction (Mohit et. al, 2010). Thus, it can be concluded that understanding students' satisfaction predicting factors can assist universities to undertake changes to increase satisfaction among them. However, there is a paucity of research on student housing satisfaction factors especially in Malaysia. Hence, this study is an attempt to fill this gap to a certain degree. Consequently, the current study seeks to identify the most important factors that predict students' satisfaction with their on campus accommodation in Universiti Sains Malaysia hostels. The following section provides a discussion on factors that influence satisfaction with regard to campus accommodation. This is followed by a discussion on the methodology utilized in this study, data analysis and a discussion on the findings.

\section{Satisfactions with hostel influencing factors}

Among the studies that investigate the influence of physical attributes of campus accommodation on students' satisfaction is Kayas' and Erkip's research (2001) on student housing setting at Bilkent University, Ankara.The study reveals that students living on the highest floor perceived their rooms larger and found them less crowded in comparison to those on the lowest floor. The study postulates that students' perception of their privacy led to an increase in the level of students' satisfaction with their living condition. Similarly, Karlin, et al.'s study (1979) posits that hostel room size can indeed influence students' level of satisfaction. For instance, their study found that students who lived in triple sharing rooms were less satisfied and unhappier with their living conditions than students residing in double sharing rooms. Other related studies also indicate that there is a high demand among students for a greater degree of privacy in their halls of residence. For example, Balogh et al.'s (2005) study that looked at the recent trends in housing construction and renovation of educational institutes involving 284 online respondents reveals that "construction and renovation were focused mainly on building apartments and suites rather than traditional residence halls" (p. 55) as a result of the demand for more privacy. Privacy, feeling of crowding and control over space have also been the focus in a variety of studies in student housing as an important predicting factor of satisfaction (such as Walden et. al., 1981, Vinsel et al., 1980). These studies report that the physical factors of the 'built environment' affect the people's perception of privacy and crowding.

There are also studies that investigated the influence of high rise buildings vs. low rise buildings among undergraduates. Holahan and Wilcox (1978), for example, who conducted a study on 120 freshmen residents in university accommodations came to a conclusion that "residents of low-rise dormitories were significantly more satisfied and established more dormitory-based friendships than residents of a mega-dorm setting." (p. 237). In a similar vein, Baum et al. (1979) claim that the design of high rise accommodations also have a strong influence on the satisfaction levels of students. They argue that buildings with long corridors (as opposed to shorter ones) tend to provide a more positive experience to the residents as it gave them a sense of less-crowdedness. However, the study notes that residents living in dormitories with long corridors are often accompanied by an increased level of competitiveness, social withdrawal, reduced cooperativeness and, lower personal control (cited in Kaya and Erkip, 2001, 36, 37).

At this juncture, it must also be noted that the demographic background of students like gender and age also impacts their satisfaction levels. For instance, males and females tend to have different perceptions on the 'feeling of crowding' and subsequently have different coping strategies to the crowded conditions (Walden et. al., 1981). A case study at Kuwait University by Alkandari (2007) investigated students' perceptions of the residence hall living environment. His study shows how students' perceptions are affected by gender, nationality and duration of residence. The study found that female and male responses were significantly different in the way they perceived their residence hall environment: generally female students were more satisfied than male students with their residence hall environment. However, there were no significant differences in responses between students of different nationalities. Along similar lines, Allen and Maimone's (1989) study among 855 students concluded that the year of study was important in terms of both perceptions of, and satisfaction with, the residence experience. Specifically, first year students rated themselves as feeling "less involved" and "less a part 
of the community" than did their upper-year counterparts." (Cited in Rodger and Johnson, 2005:88, 89)

In another related study, $\mathrm{Li}$ et al. (2007) examined the relationship between students' overall satisfaction with their residence hall living experience in terms of university hostel facilities and students' satisfaction with various custodial, maintenance, and services. Findings of this study indicate that "interpersonal environment was more important than cleanliness and maintenance variables in predicting students' satisfaction with their residence experiences" (p.50).

There has been a vast array of studies that investigated the effects of on-campus accommodation on students. The studies conclude that campus accommodation generally provides a positive impact on its residents. Among the positive effects are: more engagement with the academic environment (Astin 1973, 1993), higher rates of graduation (Pascarella \& Terenzini, 1991; Tinto, 1993; Chickering 1974 ), greater satisfaction with college experiences (Blimling, 1993), a greater perception of personal growth (Schroeder \& Mable, 1994), better social interaction (Ballou, Reavill, \& Schultz, 1995), higher educational aspirations and better academic performance (Moos and Lee 1979).

Besides, research in this area generally supports the notion that "students living in-campus organized housing tend to be more socially adjusted and tend to participate more often in extracurricular and campus activities than students living off-campus (Feldman \& Newcomb, 1969; Lundgren \& Schwab, 1979; cited in Rinn, 2004) In addition, Cross and others (2009) who conducted an investigation among 440 students living on-campus found that the hostel environment can influence the student's alcohol use: "a hall with suites increases the situational motivation to drink alcohol." (p. 597). In a study on 502 first-time-college students Pike (2009) examined "the effects of on- and off-campus living arrangements on students" "openness to diversity". The result of his study suggests that "living on-campus was directly associated with significantly higher levels of openness to diversity than living off-campus." (p. 629). Moos and Lee (1979) suggest that "students in independent houses perceived the highest levels of supportive achievement, independence, and intellectual orientation" (p. 212).

The review of related literature reveals that less attention has been given on the most important predictors of students' housing satisfaction and comparison between various students' accommodation. In the context of this study, Universiti Sains Malaysia offers a range of on campus accommodation with different designs and facilities located inside and outside of campus. This researcher opines that these categories of housing facility have their own advantages and disadvantages. Consistent with this view, the following research questions are addressed in this study

- What are the most important factors which predict students' satisfaction with hostels?

- Do hostels inside campus and outside campus differ significantly in their level of satisfaction? If yes, what are the factors that bring about this difference?

- Which is the hostel that is perceived as the most favorable hostel among students?

The outcome of this study can be useful for university administrators to understand the students' needs and satisfaction predictors to keep students more satisfied with their university housing.

\section{Methodology}

The current study was conducted in Universiti Sains Malaysia (main campus) hostels. In the context of Malaysia, student hostel (Asrama) alludes to densely populated buildings providing residential quarters for large numbers of students. In these buildings, students share rooms with one or two others and a group of them share facilities like washroom, bathrooms, laundry, TV room, and food stall etc. Universiti Sains Malaysia has a total of twelve hostels. Three of them are located outside the campus (i.e. Restu, Tekun and, Saujana) while the rest are located inside the campus (Bakti Permai, Cahaya Gemilang, Fajar Harapan, Indah Kembara, Aman Damai, International House, Murni Nurani, Lembaran, and Jaya). The International House is only occupied by local and foreign postgraduate. Hence, this hostel has not been considered in this study. From the twelve hostels only seven hostels were selected for this study. They are (Cahaya Gemilang, Fajar Harapan, Indah Kembara, Aman Damai, Restu, Tekun and, Saujana).

In USM, male and female hostels are segregated and each hostel provides sleeping quarters, laundry, TV room, and so forth. However, they share a common food court. In the on campus hostels, rooms are located along corridors while the three outside-campus hostels have four double rooms grouped around a corridor with some toilets and bathrooms. The door of each four rooms opens to a transitional space .These groups of building are separated from the main corridor in each wing by a set of staircase.

A sample population of 288 students (220 females; and 68 males) was used for the study. The participants were 
recruited from the seven hostels (inside-campus and outside-campus) of Universiti Sains Malaysia and each participant was initially required to fill up a demographic form. The demographic form sought information on gender, age, race, marital status, religious affiliation, duration of stay, current hostel accommodation and year of study.

Later with the consent of the subjects, the Hostel Satisfaction Questionnaire for measuring hostel satisfaction was administered. Data was collected from December 2009 to January 2010. The questionnaire consisted of 28 -items. The items that were rated by the students were: 1) hostel exterior, 2) distance from university facilities, 3) transport facility, 4) hostel's population, 5) hostel's security, 6) hostels room safety, 7) hostel room size, 8) satisfaction with fees, 9) hostel's other facility, 10) food quality, 11) satisfaction with maintenance and cleanliness, 12) satisfaction with rules and regulation, and 13) physical condition. The participants rated on 5-point rating scale their responses from very dissatisfied (1) to very satisfied (5). In this sample, the reliability coefficient is $=.632$

\section{Results}

The Statistical Package for the Social Sciences (SPSS), version 17.0 was used for all data analysis. Descriptive statistics were applied on demographic information. To test the first hypothesis, "the most important factors which predict students' satisfaction with on-campus accommodation", factor analysis was performed on the data collected. For the second hypothesis, "Do hostels inside-campus and outside-campus differ significantly in their level of satisfaction", t-test was used to analyze the data. The third hypothesis, "What is the most favorable hostel among undergraduate students", percentages were obtained.

The participants of the study consisted of 288 students (220 females; and 68 males) from seven hostels of Universiti Sains Malaysia. Among them 48.3\% students were from inside-campus and $51.7 \%$ were from outside-campus hostels. In outside-campus hostels, students were from (Restu, 26.1\%, Tekun, 13.2\%, Saujana 12.4\%). In Inside-campus hostels students were from (Bakti Permai 12.8\%, Cahaya Gemilang 15\%, Fajar Harapan, 16.4\%, Indah Kembara, 6.3\%, and Aman Damai 8.4\%). Their age ranged from 18 to 32, with an average age of 21.2 years. The ethnicities of the participants were Buddhist $(19.9 \%)$, Chinese $(0.6 \%)$, Hindus $(5.6 \%)$, Muslims (64.5\%), Malay (0.6\%), and Others $(8.8 \%)$. The marital status of the participants was: married $(0.7 \%)$, and unmarried $(99.3 \%)$. The average duration of the stay in hostels was 1.5 years. Overall, students were from: the first year (35.6\%), second year (31.5\%), third year (27.7\%), and fourth year (5.2\%). (See Table 1 for demographic information)

The data was subjected to a factor analysis using the SPSS version 17.0. The factor analysis used the extraction method of maximum likelihood and varimax rotation. The results of the factor analysis indicated that there were six factors with eigen values greater than 0.5. After inspection of the scree plot, a six-factor solution was deemed appropriate. The first factor, Factor I, was labeled "Satisfaction with hostel fees" and accounted for $57.6 \%$ of the variance $(\mathrm{M}=3.31, \mathrm{SD}=.893)$ and had a coefficient of variation of $26.8 \%$. The second factor, Factor II, was labeled "Distance from University facility" and accounted for $67.1 \%$ of the variance $(\mathrm{M}=2.97, \mathrm{SD}=1.072)$ and had a coefficient of variation of $.36 .09 \%$. The third factor, Factor III, was labeled "Satisfaction with hostel's other facilities" and accounted for $50.3 \%$ of the variance $(\mathrm{M}=3.40, \mathrm{SD}=1.000)$ and had a coefficient of variation of $.29 .4 \%$. The fourth factor, Factor IV, was labeled "Satisfaction with hostel's security" and accounted for $68.3 \%$ of the variance $(\mathrm{M}=3.02, \mathrm{SD}=.972)$ and had a coefficient of variation of $32.1 \%$. The fifth factor, Factor V, was labeled "Satisfaction with hostel's room safety" and accounted for $71.1 \%$ of the variance $(\mathrm{M}=$ $3.15, \mathrm{SD}=.927$ ) and had a coefficient of variation of $29.4 \%$. The sixth factor, Factor VI was labeled "Satisfaction with hostel's room size" and accounted for $55.0 \%$ of the variance $(\mathrm{M}=3.71, \mathrm{SD}=.902)$ and had a coefficient of variation of $24.3 \%$ (See Table 2)

The result of the study suggested that significant difference was found between inside-campus and outside-campus hostels students. On the variable of hostel exterior $(\mathrm{t}=-2.174, \mathrm{p}<.05)$; distance from university $(\mathrm{t}=6.524, \mathrm{p}<.05)$; transport facility $(\mathrm{t}=3.823, \mathrm{p}<.05)$; hostel's population $(\mathrm{t}=-2.554, \mathrm{p}<.05)$; hostel's security $(\mathrm{t}=-3.138, \mathrm{p}<.05)$; hostels room safety $(\mathrm{t}=-2.482, \mathrm{p}<.05)$; and hostel room size $(\mathrm{t}=-2.247, \mathrm{p}<.05)$ significant difference was found. Furthermore, no difference was found on the variable of satisfaction with fees $(\mathrm{t}=1.338$, $\mathrm{p}>.05)$; hostel's other facility $(\mathrm{t}=-.878, \mathrm{p}>.05)$; food quality $(\mathrm{t}=-1.687, \mathrm{p}>.05)$; satisfaction with maintenance and cleanliness $(\mathrm{t}=.315, \mathrm{p}>.05)$; satisfaction with rules and regulation $(\mathrm{t}=-.595, \mathrm{p}>.05)$; and physical condition $(\mathrm{t}=-1.814, \mathrm{p}>.05)$. See Table 3

According to the results, (28.7\%) students preferred Cahaya Gemilang, (19.2\%) for Bakti Permai ,(13\%) for Tekun, (9.8\%) for Saujana, (8.7\%) for International House, (7.6\%) for Fajar Harapan, (5.3\%) for Restu, (4.5\%) for Aman Damai, and (3.2\%) for Indah Kembara. (See table 4) 


\section{Discussion}

The primary purpose of this research was to identify the most important factors which predict students' hostels satisfaction. Based on literature review it was also hypothesized that there would be differences in the satisfaction level between inside-campus and outside-campus hostels students and on the most favorable hostel among students. The study also attempted to identify what are the most important factors which predict students' satisfaction with their university hostel.

The data (satisfaction with fees, distance from university facilities, satisfaction with hostels room safety, satisfaction with hostel room size, satisfaction with hostel's security, and satisfaction with hostel's other facility) was reduced through a factor analysis using the principal components and the varimax rotation method. The six factors had eigen values of 0.5 or more and only the variables with factor loadings of more than 0.5 were selected. This result suggested that satisfaction with fees, distance from university facilities, satisfaction with hostels room safety, satisfaction with hostel room size, satisfaction with hostel's security, and satisfaction with hostel's other facility were the most important factors which predict students' satisfaction with hostel.

In the study, significant differences were found between inside-campus and outside-campus hostel students' level of satisfaction. The result supported the hypothesis that there would be difference in the satisfaction level between inside-campus and outside-campus hostels students. On the variable of "satisfaction with hostel fees" there was an insignificant difference $(\mathrm{n}=288, \mathrm{t}=1.338, \mathrm{p} \geq .05)$. The possible explanation of this finding was that both inside and outside-campus hostels fee charges were approximately the same except the Indah Kembara hostel. The Indah Kembara hostel fee was lower due to its triple sharing accommodation. In comparison, the other hostels offer double sharing accommodation. The variable of "satisfaction with hostel exterior" showed a significant difference $(\mathrm{n}=288, \mathrm{t}=-2.174, \mathrm{p} \leq .05)$ between outside and inside-campus hostel. In outside-campus hostel, which include Tekun, Restu, and Saujana, students were more satisfied as compared to inside-campus hostels. The exterior of outside campus hostels is more attractive and they are situated in a more beautiful location in a vast open space, In addition, they are much newer compared to the in-campus hostels.

A result of the study on the variable of "distance to university facilities" showed a significant difference $(\mathrm{n}=288$, $\mathrm{t}=6.524, \mathrm{p} \leq .05)$ and inside-campus hostel students showed more satisfaction. The possible explanation of this finding is that as inside-campus students are in the campus vicinity of Universiti Sains Malaysia. As such, access to their lecture hall, library, clinics, post office, book store, sports complex, museum, conference hall, and bank is much easier to inside-campus hostels students in comparison to outside-campus hostels students. Furthermore, on the variable of "satisfaction with transport facility" a significant difference was also found $(\mathrm{n}=288, \mathrm{t}=3.823, \mathrm{p}$ $\leq .05$ ) between inside and outside-campus hostel students. Inside-campus hostels students showed more satisfaction with the transport facility provided. These findings are in line with Sommer (1968) who suggests: "as the distance from campus increases, student feel more isolated from the social life on campus" (Cited in Oppewal et al 2005:114). The variable "satisfaction with hostel facilities" provided by the hostel include clinics, library, conference hall, book store etc. The inside-campus and outsides-campus hostel students results demonstrated insignificant difference $(\mathrm{n}=288, \mathrm{t}=-.878, \mathrm{p} \geq .05)$ on the variable of satisfaction with facilities provided by the hostel. There is no difference between both categories of hostel students.

On the satisfaction of the inside and outside-campus hostels students on the variable of "hostel population", a significant difference was found $(\mathrm{n}=288, \mathrm{t}=-2.554, \mathrm{p}<.05)$. Outside-campus hostels student were more satisfied than inside-campus hostels students. The possible reason of this finding is that the outside-campus hostel provided more double sharing opportunities. Besides, the rooms are more spacious and this is expected to increases the level of privacy as students feel less crowded. These findings are consistent with Barona et al. (1976) who explored the impact of social density (an increase in number of roommates sharing a double occupancy) on students' perception of crowding. Their results revealed that "residents of triples expressed greater feelings of crowding, perceived less control over room activities, expressed more negative interpersonal attitudes, and experienced a more negative room ambience" (p.434).

On the variable of "satisfaction with hostel security" significant difference was found $(\mathrm{n}=288, \mathrm{t}=-3.138, \mathrm{p} \leq .05)$, inside-campus hostel students were more satisfied than outside-campus hostels students. The possible explanation of this finding is that as inside-campus hostels are in-campus of Universiti Sains Malaysia they feel more secure as compared to outside-campus hostels. According to Smith (2000), students are now looking for housing with more of a residential design with security, community spaces, and privacy. On the variable of "satisfaction with room safety" a significant difference was found $(\mathrm{n}=288, \mathrm{t}=-2.482, \mathrm{p} \leq .05)$ between inside-campus hostel and outside-campus hostel students. Inside-campus hostel students were more satisfied than outside-campus hostel students. 
In addition, on the variable of "satisfaction with hostel's food quality" an insignificant difference was found $(\mathrm{n}=288, \mathrm{t}=-1.687, \mathrm{p} \geq .05)$ between inside-campus hostel and outside-campus hostel students. The result demonstrates that both categories of students were satisfied with the quality of food provided. According to the results, insignificant difference $(\mathrm{n}=288, \mathrm{t}=.315, \mathrm{p} \geq .05)$ was found on the variable of "satisfaction with hostel's maintenance \& cleanliness" between inside-campus hostel and outside-campus hostel students.

The results on the variable of "satisfaction with hostel's rules \& regulation" demonstrates insignificant difference $(\mathrm{n}=288, \mathrm{t}=-.595, \mathrm{p} \geq .05)$ between inside-campus hostel and outside-campus hostel students. The possible explanation of this finding is that the rules and regulation of hostels in different hostels are almost the same. On the variable of "satisfaction with room size" significant difference was found $(n=288, t=-2.247, p \leq .05)$. The outside-campus hostel students were more satisfied than inside-campus hostel students. The possible reasons of this finding are that outside-campus hostels provide more spacious room and the majority of the rooms are designed for double sharing. The variable "satisfaction with physical condition of hostel" showed insignificant difference ( $\mathrm{n}=288, \mathrm{t}=-1.814, \mathrm{p} \geq .05$ ) between inside-campus hostel and outside-campus hostel students. The physical condition of hostels include ventilation, bed, study table, toilet sharing, and lighting, etc.

The result of the study reveals that the most preferred hostel by the students was Cahaya Gemilang (28.7\%). Cahaya Gemilang is located inside-campus of Universiti Sains Malaysia. The main reasons that made "Cahaya Gemilang" take top rank was its good internet facility, strategic location and closeness to main facilities such as library, lecture halls etc. This is reflected in one of the remarks made by a student living there: "I stay in Cahaya Gemilang and I am totally satisfied, I shouldn't wake up very early in the morning I can walk to lecture hall and if I need any thing in my room I can easily come back and take it, if I want to take a shower after my class it is also very easy. Generally the situation of Cahaya Gemilang is very strategic it is centrally located in the campus and is therefore near to all the main facilities in USM".

There are some limitations of the study. First, only seven hostels were selected in this study; therefore, the generalizability of the findings is limited. Second, more females $(76 \%)$ respondents were used in the study. Further investigations should include equal number of males and females. Despite the limitations, it can be safely concluded that the findings indicate that there are significant differences in the satisfaction level among students living in different hostels for various reasons which will be presented in the concluding section below.

\section{Conclusion}

To conclude, the main finding of this study is that inside and outside campus hostels students had significantly different levels of satisfaction. Among the seven hostels investigated in this study, "Cahaya Gemilang" was the most preferred hostel among the students. The study's findings suggest that the most important factors that predict students' satisfaction with their hostels are the rental rates, distance from university facilities, room safety, room size, hostel security, and the hostel's other facilities. The findings of this study should therefore be considered by the university management in their attempt to improve the quality of their hostels.

\section{References}

AlKandari, N. (2007). Students' perceptions of the residence hall living environment at Kuwait University. College Student Journal, 41(2), 327-335.

Amole, D. (2009). Residential satisfaction in students' housing. Journal of Environmental Psychology, 29, 76-85.

Astin, A. W. (1973). The impact of dormitory living on students. Educational Record, 54, 204 -210.

Astin, A. W. (1993). What matters in college? Four critical years revisited. San Francisco: Jossey-Bass.

Ballou, R., Reavill, L., \& Schultz, B. (1995). Assessing the immediate and residual effects of the residence hall experience: Validating Pace's 1990 study of on-campus and offcampus students. Journal of College and University Student Housing, 25, 16-21.

Balogh, C. P., Grimm, J., \& Hardy, K. (2005). ACUHO-I Construction and Renovation Data: The Latest Trends in Housing Construction and Renovation. Journal of college and university student housing, 33(2).

Bekurs, G. (2007). Outstanding student housing in American community colleges: problems and prospects. Community College Journal of Research and Practice, 31, 621-636.

Blimling, G. S. (1993). The influence of college residence halls on students. In J. Smart (Ed.), Higher education: Handbook of theory and research. Volume IX (pp. 248-307). New York: Agathon. 
Chickering, A. (1974). Commuting versus resident students: Overcoming educational inequities of living off campus. San Francisco: Jossey-Bass.

Cross, J. E., Zimmerman, D., \& O’Grady, M. A. (2009). Residence Hall Room Type and Alcohol Use Among College Students Living on Campus. Environment and Behavior, Vol. 41 (4).

Holahan, C. J., \& Wilcox, B. L. (1978). Residential satisfaction and friendship formation in high and low rise student housing: an interactional analysis. Journal of Educational Psychology, 70(2), 237-241.

Karlin, R. A., Rosen, L. S., \& Epstein, Y. M. (1979). Three Into Two Doesn't Go: A Follow-up on the Effects of Overcrowded Dormitory Rooms. Personality and Social Psychology Bulletin, 5(3), 391-395.

Kaya, N., \& Erkip, F. (2001). Satisfaction in a Dormitory Building: The Effects of Floor on the Perception of Room Size and Crowding Environment and Behaviour, 33(1), 35-53.

Li, Y., Mack C. Sheely, I., \& Whalen, D. F. (2005). Contributors to Residence Hall Student Retention: Why do Students Choose to Leave or Stay? Journal of college and University student housing 33(2).

Mohit, M. A., Ibrahim, M., \& Rashid, Y. R. (2010). Assessment of residential satisfaction in newly designed public low-cost housing in Kuala Lumpur, Malaysia. Habitat International, 34(1), 18-27.

Moos, R., \& Lee, E. (1979). Comparing residence hall and independent living settings. Research in Higher Education, 1(3).

Oppewal, H., Poria, Y., ravenscroft, N., \& Speller, G. (2005). student preferences for University accomodation: an application of the stated preference approach. In R. G. Mira (Ed.), Housing, space and quality of life: Ashgate publishing limited.

Pascarella, E. T., Terenzini, P T, \& Blimling, G. S. (1996). Students' out-of-class experiences and their influence on learning and cognitive development: A literature review. Journal of College Student Development, 40, 610-623.

Rinn, A. N. (2004). Academic and social effects of living in honors residence halls. Journal of the National Collegiate Honors Council, 5(2), 67-79.

Rodger, S. C., \& Johnson, A. M. (2005). The Impact of Residence Design on Freshman Outcomes: Dormitories Versus Suite-style residences. The Canadian Journal of Higher Education, 35(3), 83-99.

Schroeder, C. C, \& Mable, R. (1994). Residence halls and the college experience: Past and present. In C. Schroeder \& R Mable (Eds.), Realizing the educational potential of residence halls (pp. 3-21). San Francisco: Jossey-Bass.

Smith, J. J. (2000). Great expectations. Buildings, 94(3), 28-32.

Tinto, V. (1993). Leaving college: Rethinking the causes and cures of students attrition ( ${ }^{\text {nd }}$ ed.). Chicago, IL: The University of Chicago Press.

Vinsel, A., Brown, B. B., Altman, I., \& Foss, C. (1980). Privacy Regulation, Territorial Displays, and Effectiveness of Individual Functioning. Journal of Personality and Social Psychology, 39(6), 1104-1115.

Walden, T. A., Nelson, P. A., \& Smith, D. E. (1981). Crowding, Privacy, and Coping. Environment and Behaviour, 13(2), 205-224. 
Table 1. Frequency table for respondents' demographic information

\begin{tabular}{|c|c|c|c|c|c|}
\hline \multicolumn{2}{|c|}{ Demographic Variables } & \multirow{2}{*}{$\begin{array}{c}\text { Percentage } \\
76.8 \%\end{array}$} & \multicolumn{2}{|c|}{ Demographic Variables } & \multirow{2}{*}{$\begin{array}{c}\text { Percentag } \\
\\
0.7 \%\end{array}$} \\
\hline Gender & Female & & $\begin{array}{l}\text { Marital } \\
\text { status }\end{array}$ & Married & \\
\hline & Male & $23.2 \%$ & & Unmarried & $99.3 \%$ \\
\hline \multirow[t]{5}{*}{ Age } & $18-21 \mathrm{yrs}$ & $61.4 \%$ & $\begin{array}{l}\text { Years in the } \\
\text { University }\end{array}$ & 1st Year & $35.6 \%$ \\
\hline & $22-25 \mathrm{yrs}$ & $36.7 \%$ & & 2nd Year & $31.5 \%$ \\
\hline & 26 or more & $1.9 \%$ & & 3rd Year & $27.7 \%$ \\
\hline & & & & 4th Year & $5.2 \%$ \\
\hline & Islam & $65.1 \%$ & $\begin{array}{l}\text { Duration of } \\
\text { the Stay in } \\
\text { the Hostels }\end{array}$ & $0-3$ months & $23.6 \%$ \\
\hline \multirow{3}{*}{ Religion } & Buddhist & $19.9 \%$ & & 6-12 months & $18.7 \%$ \\
\hline & Hindu & $06 \%$ & & $1-2$ years & $22.5 \%$ \\
\hline & & & & 2 or more years & $19.5 \%$ \\
\hline \multirow[t]{7}{*}{ Ethnicity } & Chinese & $0.6 \%$ & $\begin{array}{l}\text { Hostels of } \\
\text { Universiti of }\end{array}$ & Bakti Permai & $6.8 \%$ \\
\hline & Hindus & $5.6 \%$ & $\begin{array}{l}\text { Sains } \\
\text { Malaysia }\end{array}$ & Cahaya Gemilang & $14.8 \%$ \\
\hline & Malay & $0.6 \%$ & & Fajar Harapan & $4.2 \%$ \\
\hline & Buddhist & $19.9 \%$ & & Indah Kembara & $5.7 \%$ \\
\hline & Muslims & $64.5 \%$ & & Restu & $28.1 \%$ \\
\hline & Others & $8.8 \%$ & & Saujana & $25.1 \%$ \\
\hline & & & & Tekun & $15.3 \%$ \\
\hline
\end{tabular}

Table 1 indicates frequencies and percentages for demographic information i.e. gender, age, religion, ethnicity, marital status, stay duration, years in the university, and hostel 
Table 2. Factor Loadings for the Satisfaction of the Students toward Hostels of Universiti of Sains Malaysia

\begin{tabular}{|l|l|}
\hline Item & Factor Loading \\
\hline Satisfaction with Hostel's Fees & .576 \\
\hline Distance from University Facility & .671 \\
\hline Satisfaction with Hostel's others Facilities & .503 \\
\hline Satisfaction with Hostel's Security & .683 \\
\hline Satisfaction with Hostel's Rooms Safety & .711 \\
\hline Satisfaction with Hostel's Room Size & .550 \\
\hline
\end{tabular}

Note: With loadings more than .05 was selected

Table 3. The mean difference on the variables of Hostel Satisfaction (Inside-Campus and Outside-Campus)

\begin{tabular}{|c|c|c|c|c|c|c|c|}
\hline Variable & Hostel Location & $\mathbf{N}$ & Mean & Std Dev & $\mathbf{t}$ & df & Sig (2- tailed) \\
\hline \multirow[t]{3}{*}{ Satisfaction with Fees } & Inside-campus & 143 & 3.35 & .906 & & & \\
\hline & & & & & 1.338 & 286 & .182 \\
\hline & Outside-campus & 145 & 3.21 & .904 & & & \\
\hline Satisfaction with Hostel & Inside-campus & 143 & 3.51 & .963 & & & \\
\hline \multirow[t]{2}{*}{ Exterior } & & & & & -2.174 & 286 & .031 \\
\hline & Outside-campus & 145 & 3.74 & .864 & & & \\
\hline Distance from University & Inside-campus & 143 & 3.24 & 1.188 & 6.524 & 286 & .000 \\
\hline
\end{tabular}




\begin{tabular}{|c|c|c|c|c|c|c|c|}
\hline Facilities & Outside-campus & 145 & 2.40 & 1.003 & & & \\
\hline Satisfaction with & Inside-campus & 143 & 3.20 & 1.045 & & & \\
\hline \multirow[t]{2}{*}{ Transport Facilities } & & & & & 3.823 & 286 & .000 \\
\hline & Outside-campus & 145 & 2.73 & 1.049 & & & \\
\hline Satisfaction with Hostel & Inside-campus & 143 & 3.31 & .989 & & & \\
\hline \multirow[t]{2}{*}{ Other Facilities } & & & & & -.878 & 286 & .381 \\
\hline & Outside-campus & 145 & 3.42 & 1.058 & & & \\
\hline \multirow[t]{3}{*}{ Hostel Residents } & Inside-campus & 143 & 3.48 & .749 & & & \\
\hline & & & & & -2.554 & 286 & .011 \\
\hline & Outside-campus & 145 & 3.69 & .672 & & & \\
\hline Satisfaction with Hostel & Inside-campus & 143 & 3.19 & .952 & & & \\
\hline \multirow[t]{2}{*}{ Security } & & & & & -3.138 & 286 & .002 \\
\hline & Outside-campus & 145 & 2.84 & .962 & & & \\
\hline Satisfaction with & Inside-campus & 143 & 2.90 & 1.037 & & & \\
\hline \multirow[t]{2}{*}{ Hostel's Food Quality } & & & & & -1.687 & 286 & .093 \\
\hline & Outside-campus & 145 & 3.09 & .841 & & & \\
\hline Satisfaction with & Inside-campus & 143 & 3.26 & 1.019 & & & \\
\hline Hostel's Maintenance \& & & & & & .315 & 286 & .753 \\
\hline Cleanliness & Outside-campus & 145 & 3.22 & 1.031 & & & \\
\hline Satisfaction with Hostels & Inside-campus & 143 & 3.28 & .933 & & & \\
\hline \multirow[t]{2}{*}{ Room Safety } & & & & & -2.482 & 286 & .014 \\
\hline & Outside-campus & 145 & 3.01 & .904 & & & \\
\hline Satisfaction with & Inside-campus & 143 & 3.32 & .836 & & & \\
\hline Hostel's Rules \& & & & & & -.595 & 286 & .552 \\
\hline Regulation & Outside-campus & 145 & 3.38 & .809 & & & \\
\hline Satisfaction with Room & Inside-campus & 143 & 3.20 & .908 & & & \\
\hline \multirow[t]{2}{*}{ Size } & & & & & -2.247 & 285 & .025 \\
\hline & Outside-campus & 145 & 3.38 & 1.048 & & & \\
\hline Satisfaction with & Inside-campus & 143 & 3.59 & .974 & & & \\
\hline \multirow{2}{*}{$\begin{array}{l}\text { Physical Condition of } \\
\text { Hostel }\end{array}$} & & & & & -1.814 & 286 & .071 \\
\hline & Outside-campus & 145 & 3.83 & .822 & & & \\
\hline
\end{tabular}

Note. Shows difference in satisfaction with inside-campus and outside-campus hostels of Universiti of Sains Malaysia 
Table 4. Percentages of Preferred Hostels

\begin{tabular}{lc}
\hline Preferred Hostel & Percentage \% \\
\hline Bakti Permai & $19.2 \%$ \\
Cahaya Gemilang & $28.7 \%$ \\
International House & $8.7 \%$ \\
Aman Damai & $4.5 \%$ \\
Restu & $5.3 \%$ \\
Tekun & $13.0 \%$ \\
Saujana & $9.8 \%$ \\
Fajar harapan & $7.6 \%$ \\
Indah Kembara & $3.2 \%$ \\
\hline
\end{tabular}

Table 4 indicates percentages for preferred hostels by the respondents 